\title{
Onus Orbis Terrarum: About a Possible Shift in the Definition of Sovereignty
}

Millennium: Journal of International Studies 2016, Vol. 44(3) 305-320

(C) The Author(s) 2016

Reprints and permissions: sagepub.co.uk/journalsPermissions.nav DOI: I0.I|77/03058298|6640608 mil.sagepub.com

(SAGE

\section{Bruno Latour}

Sciences Po, Paris, France

\begin{abstract}
Starting with an insight from Peter Sloterdijk about the enduring notion of Empire in the European idea of sovereignty, this article explores a problem common to the discipline of International Relations, and more generally, geopolitics as well as social theory: the very origin of the notion of an entity endowed with some sort of autonomy over a territory. It is argued that the notion of a bounded entity triggers many artifacts that explains, in part, the failure and denial of world politics, especially over the question of climate change.
\end{abstract}

\section{Keywords}

Sloterdijk, Whitehead, actor-network theory, geopolitics, empire

'Cette ouverture du jeu économique sur le monde implique évidemment une différence de nature et de statut entre l'Europe et le reste du monde. C'est à dire que d'un côté ce sera l'Europe, les Européens qui seront les joueurs, et le monde, eh bien, il sera l'enjeu.

Le jeu est en Europe, mais l'enjeu c'est le monde'

- Michel Foucault ${ }^{1}$

1. [English translation: 'Now, ... this opening of the economic game onto the world clearly implies a difference of both kind and status between Europe and the rest of the world. That is to say, there will be Europe on one side, with Europeans as the players, and then the world on the other, which will be the stake. The game is in Europe, but the stake is the world'.] Michel Foucault, The Birth of Biopolitics: Lectures at the Collège de France, 1978-1979 (translated by Graham Burchell), (New York: Picador Press, 2008): 55.

\section{Corresponding author:}

Bruno Latour, Sciences Po, 27 Rue Saint-Guillaume, 75007 Paris, France. 


\section{One Remaining Empire: the Globe}

In a small book with the uplifting title If Europe Wakes Up, Peter Sloterdijk defines the essence of Europe by its obsession for carrying, from generation to generation, the tradition of the emblem of Empire. 'The quintessential function of European constitution', he writes, 'depends on a mechanism to transfer the Empire'. ${ }^{3}$ In the eyes of Sloterdijk, it is such a transfer that has always created a highly conflicted relationship to the much narrower notion of national state boundaries. He argues that, from the Roman Empire to the 20th century, it is this conflict that has defined the centuries-long thrust forward of Europe, for better or worse. 'For a millenary, Europe is a procession during which are transported the signs of an unforgettable form of power', he says. ${ }^{4}$ This process of translation explains, according to Sloterdijk, why, if anyone wishes to think like a real European, he or she must necessarily always 'think big'. Hence, the not very politically correct subtitle of this odd essay: 'Some thoughts on a world program for a world power at the end of its political absence'! And he concludes: 'What is certain is that a secular European politics adapted to our times, should be able to tell what vision it has of the greatness of Spirit'. 5

Totally indifferent to what could render such a claim outmoded or even perverse after so much post-colonial analysis, Sloterdijk, with his usual solemn, and, well, imperial tone of authority, explains that it would be stupid to expect any sort of return to 'this maniacal expansionism triggered by the belief that [Europe] had been chosen to exert seigneurage rights on the world' ${ }^{6}$ After post-colonial studies has succeeded in linking Europe's power grab with colonisation, it simply means that for the former imperial powers there nonetheless remains a crucial task: to still cope with the long-term consequences of this translatio imperii: 'To be European today in any ambitious sense, is to conceive the revision of the principle of Empire as the highest mission for theory as well as for practice'.?

In other words, even if Europe has been thoroughly 'provincialized', to use Chakrabarty's famous expression, ${ }^{8}$ this by now tiny segment of the world still has on its shoulders the burden to think of an alternative to the principle of sovereignty that it has imposed everywhere (including in its North American incarnation, where, from Washington, DC, to universities designed by Thomas Jefferson, everyone dreams of domes, columns, and senators in togas, as if the Roman Empire had been remade by Hollywood in a costly and kitschy political peplum). It is not because it has been debased by the universal idea of the nation-state that the principle of sovereignty is no longer

2. Peter Sloterdijk, Si l'Europe s'éveille (Paris: Mille et une nuits, 2003).

(I translate from the French 'Falls Europa erwacht Gedanken zum Programm einer Weltmacht am Ende des Zeitalers ihrer politischen Absence', Suhrkamp, 1994).

3. Sloterdijk, Si l'Europe s'éveille, 57.

4. Ibid., 54 .

5. Ibid., 82.

6. Ibid., 80 .

7. Ibid., 74.

8. Dipesh Chakrabarty, Provincializing Europe: Postcolonial Thought and Historical Difference (Chicago: The University of Chicago Press, 2000). 
present, and in some odd and enigmatic form, reflected in the emblems of the Empire. We have yet to discover what could serve as a plausible successor to the notion of the Globe that gave shape to the imperial idea of a universal power grab.

After the long 'neurotic depression' of the post-war period (the title of another strange essay by Sloterdijk), ${ }^{9}$ Europe, for this philosopher, still bears the onus orbis terrarum. Not, mind you, because like a new Atlas, it should bear the orb of the Earth on its back; not because the depressed and guilt-ridden post-historical European Union should relinquish forever such a burden; but because, no matter what it did in the past, it remains the task of Europe to metamorphose once again what it means to be 'global'. It is impossible for Europe to simply be happy being provincialised, and to simply nurse its wounds in the hope that from now on it can live modestly and in shame, ignoring history altogether.

Europe, in Sloterdijk's argument, cannot be content with beating its chest in a continuous mea culpa, mea maxima culpa, without retracing its steps and understanding why it is that it has drawn the global map inside which it has now become a province. A modest and retreating Europe is in nobody's interest. Nor was it in anybody's interest, in an earlier period, to have it overblown as a world centre and the unique source of imperial dominion. As the epicentre of two 'World Wars', it should always be very careful about wishing to be the centre of anything. But still, there must exist another way to assemble the 'concert of nations' than to go from the role of conductor to that of a silent musician! It is not enough to relinquish the task of carrying the 'burden of the white man', if you don't find out why it is that there is a Globe and a burden to be carried. ${ }^{10}$ The problem has shifted to that of understanding the global itself. Sloterdijk's argument in my reading, no matter how quaint, is that the real burden cannot be 'shrugged', to use the infamous title of Ayn Rand's bizarre novel. ${ }^{11}$

Sloterdijk's argument about the necessary importance of transforming, by transporting yet once again, the memory of the Empire, helps situate with great clarity in my view, the connection of Europe and the invention of the Globe. If postcolonial studies have succeeded in provincialising Europe, it still exerts one imperial dominion in its full and undisputed splendor, namely this strange idea that the Globe is the equivalent of the natural world. My argument is that there has been confusion between the Globe and the Earth. Such a Globe is still the undisputed, authoritative, universal, external frame inside which all geopolitical entities - be they empires, nation-states, lobbies, networks, international organisations, corporations, diasporas - are situated in a recognisable place, a province side by side with all the other provinces.

In other words, a natural Globe still offers the 'ground map' which allows any localisation to occur. It is still the universal embrace from which anyone, anywhere, may point to a site and decide that such a situation, such an event, is local. The system of coordinates that allows the localisation of any site remains intact. Nobody can stake a claim to power without its position being relativised and instantly situated, while the system of

9. Peter Sloterdijk, Théorie des après guerres. remarques sur les relations Franco-Allemandes depuis 1945 (Paris: Maren Sell Editeurs, 2008).

10. Ulrich Beck and Edgar Grande, Cosmopolitan Europe (Cambridge: Polity Press, 2014).

11. Ayn Rand, Atlas Shrugged (New York: Penguin, 2007 [1952]). 
coordinates that allows for such a localisation is absolute and remains in the background, fully invisible. To put it more dramatically, the concept of the Globe allows geopolitics to unfold in just the same absolute space that was used by physicists before Einstein. Geopolitics remains stubbornly Newtonian. All loci might be different, but they are all visualised and pointed to on the same grid. They all differ from one another, but in the same predictable way: by their longitude and latitude.

What is amazing if you look at geopolitical textbooks, is that, apparently, the Globe remains a universal, unproblematic, and uncoded category that is supposed to mean the same thing for everybody. But for me, this is just the position that marks, without any doubt, the imperial dominion of the European tradition that is now shared, or so it seems, by everyone else. ${ }^{12}$

I want to argue that the problem raised by the link between Europe and the Globe is that of understanding, as Peter Sloterdijk suggests, why it is that the onus orbis terrarum has been spread so efficiently that it has become the only space for geopolitics to unfold. Why is it that the res extensa, to use a Latin term that pertains to the history of art as well as of science and of philosophy, has been extended so much? ${ }^{13}$

Instead of asking what vision of the Globe Europe should develop, it seems to me that the question should be: is Europe allowed to think grandly and radically enough to get rid of 'the Globe' as the unquestioned space for geopolitics? If it is the result of European invention and European dominion, this does not mean that it should remain undisputed. If there is one thing to provincialise, in addition to Europe, it is the idea of a natural Globe itself. We should find a way to provincialise the Globe, that is, to localise the localising system of coordinates that is used to pinpoint and situate, relative to one another, all the entities allowed to partake in geopolitical power grabs. This is the only way, it seems to me, to detach the figure of the emerging Earth from that of the Globe.

Why would that be a specifically European task; its unavoidable responsibility? Because this image of the Globe is a highly complex and still fully active mix of several layers of imperial projections: the long gone but obviously still present shadow cast by the Roman Empire; the odd figure of God the Creator fused with that of the Emperor; the long history of mapping and of cartography, adding orbs after orbs, dome after dome, mixing many images of the Orbis Terrarum with that of the Blue Planet; all of those successive translations absorbed in some way inside the idea of the Globe of Nature, or rather, of Nature as inevitably a Globe inside which everything resides. ${ }^{14}$ This image of

12. Jerry Brotton, A History of the World in Twelve Maps (Harmondsworth: Penguin, 2013); Franco Farinelli, De la raison cartographique (traduit par Katia Bienvenu) (Paris: CTHS-Editions, 2009). Available at: http://cafe-geo.net/wp-content/uploads/raison-cartographique.pdf.

13. Valerie November, Eduardo Camacho, and Bruno Latour, 'The Territory Is the Map: Space in the Age of Digital Navigation', Environment and Planning: Society and Space 28 (2010): 581-99.

14. Peter Sloterdijk, Globes: Spheres Volume II: Macrospherology (Translated by Wieland Hoban) (Cambridge: Semiotextes, 2014); Dietrich Diederichsen and Anselm Franke, eds., The Whole Earth Catalogue: California and the Disappearance of the Outside (Berlin: Haus der Kulturen der Welt, 2013); Bruno Latour, Face à Gaïa. Huit conférences sur le nouveau régime climatique (Paris: La découverte, 2015). 
the globe, criticised by Sloterdijk in the second volume of Spheres, remains the intact empire of European dominion after having been the formatting scheme for the massive European expansion.

What is highly ironic is that the centrality of the Globe as the universal imperial figure and system of coordinates seems to totally escape the criticisms of those who lament the loss of the European central position. A now small and provincial Europe might have become fairly marginal, even though it still 'rules the world' under the Empire of Nature. Atlas has not shrugged its burden after all - at least not yet. On such an empire - the empire of cartography, the world order, the all-encompassing Globe - the sun never sets... Why shed so many tears because you are nothing more than a small spot on the map, if the mapping itself has become the universal frame within which everyone else situates themselves vis-à-vis all the others? If anything, Europe has not been provincialised enough, as long as this imperium, this hegemon, has not been metamorphosed yet again. So, following Sloterdijk's line, if there is one responsibility for Europe, it is to find an alternative to the notion of the Globe, which, right now, is a somewhat strange amalgam of the emblems of many successive empires.

Fortunately, today it's easier to provincialise nature thanks to the work of anthropologists and historians of science. 'Naturalism' is no longer described as the backdrop upon which to contrast, or through which cultures could be made visible as so many visions of the same background, but is a highly localised and historical production that is not shared, or so it seems, by any other collective ${ }^{15}$ - except of course when they have undergone the modernising transformation that imposes on them the Nature/Culture divide. This is why the notion of 'multinaturalism'16 has been introduced as the code word to provincialise, localise, and yes, relativise the many ways through which collectives collect the entities with which they enter into relations.

Through the work of many anthropologists and historians of science, it has become clear that in addition to the land grabbing that has authorised the seizure of the Earth in the past by the competing imperial European powers, there is still present a much deeper 'land drawing' that has expanded naturalism everywhere. While the first colonial expansion is clearly visible, criticised, and partially - only partially - counteracted, this other land grab remains invisible. Beneath colonial subjects that have raised their heads everywhere and protested the visions Europeans had of them, forcefully retrieving the agency denied to them and relativising all the definitions of cosmic order imposed on them, there still exist vast throngs of colonial objects just as deprived of agencies, just as silenced, and just as dominated as before. As long as this second decolonisation has not occurred, it is hard to see in what way Europe has been provincialised, and in what way it has any chance of learning how to metamorphose yet again the old imperial burden that, according to Sloterdijk, it appears to be its destiny to carry from one translatio to the next.

15. Philippe Descola, Beyond Nature and Culture, trans. Janet Lloyd (Chicago: Chicago University Press, 2013); Eduardo Kohn, How Forests Think: Toward an Anthropology Beyond the Human (Berkeley: University of California Press, 2013).

16. Eduardo Viveiros de Castro, Métaphysiques cannibales (Paris: PUF, 2009). 


\section{What is Behind the Globe of Globalisation?}

That there exists an immense and an intensely political interest in revising this hidden link between Europe and the natural Globe is rendered visible by what is usually called the ecological mutation, but what I prefer to call the New Climatic Regime. ${ }^{17}$ Obviously, something in the empire of the Global has misfired. A certain way of understanding nature, of mapping it, in the practical sense of surveys and cartography, and in the less literal way of framing its relations and building the system of coordinates that situates entities and localises sites and events, has gone terribly wrong. There is thus a great interest in 'recalling nature' much as I have advocated that we should 'recall modernity' in all the senses of the word 'recall'. That is, as what we do when we recall a memory, when we remember a task or a vocation, but also in the more mundane sense that corporations use when they have to recall a badly designed product. ${ }^{18}$

That this is a specifically European duty is made visible by the strange fact that 'naturalism' is simultaneously a very local and provincial product, and yet has expanded everywhere... For such an expansion, for such a contamination if you wish, Europeans have to accept the responsibility. Its amazing successes do not diminish its defects. It has to be recalled. That is the real 'burden of the white man': the Globe is not a space in which anyone may live. 'The Globe' is not habitable, at least the Globe painted by naturalism. And yet the pretense of naturalists, and also of those who claim to 'defend', 'protect', or 'love' nature, is that such an inhabitable, badly composed, and fully implausible format be extended to everybody. 'If only', they say, 'we could all naturalise ourselves, then we would live better, know more objectively, be more rational, and finally come together to agree in spite of all our differences'. The most divisive definition of what collects a collective is used as the shibboleth to organise world order. ${ }^{19}$ Is this not terribly ironic: Europe that has been reduced to a tiny provincial finisterre, is still able to provide the global frame for all the other powers to situate their geopolitical relations?

The task of 'denaturalising' the format with which we locate sites and events is all the more important because of the strange disconnect, or rather, the deadly disconnect, with this other typical European dominion; a dominion pointed at very early on by Karl Polanyi, that of The Economy. ${ }^{20}$ Although this second nature is more easily visible and more intensely criticised than the first nature, it is also the one that has been extended everywhere, not only to every country and every individual but also to every animal, plant, and organism. ${ }^{21}$ There is an amazing contradiction between the revolt of the colonial objects - namely the ecological mutation - and the general view that the only

17. Latour, Face à Gaïa.

18. Bruno Latour, 'The Recall of Modernity: Anthropological Approaches', trans. Stephen Muecke, Cultural Studies Review 13 (2007): 11-30.

19. Bruno Latour, Politics of Nature: How to Bring the Sciences into Democracy, trans. Catherine Porter (Cambridge: Harvard University Press, 2004).

20. Karl Polanyi, The Great Transformation (Boston: Beacon Press, 1944); Timothy Mitchell, Carbon Democracy: Political Power in the Age of Oil (New York: Verso, 2011).

21. Jason Moore, Capitalism in the Web of Life: Ecology and the Accumulation of Capital (New York: Verso, 2015). 
standard to calculate any interest, any relation, any cost and benefit, for any possible being, is to be subjected to the format of Homo oeconomicus, this very strange template invented in Europe in the 18th century and spread around the world.

Just at the moment when geopolitics has to handle the trauma of ecological mutations, proving beyond doubt that a naturalised Globe is not a plausible format to qualify any collective existence, it is just then that the individual calculator inside well-delineated boundaries celebrates its universal Triumph... At the moment when naturalisation is finally in doubt, those who are supposed to find for it a workable successor are paralysed by the format of The Economy. Naturalism, this European hegemon, is being extended everywhere under the figure of The Economy just when it was beginning to cede ground to protesting colonial objects and the realisation of other ways of collecting entities. And yet, if there is one thing to provincialise for good, it is the process of economisation. ${ }^{22}$ The link between The Economy, naturalism, and globalisation is so profound that the name of a species of human has been given to Homo oeconomicus, worthy successor in biological evolution to its outdated predecessor Homo sapiens! As long as the second nature is not relativised, the first one will never abandon its hegemonic grip.

Even though I have probably over-dramatised both of them, I hope I have clarified what is at stake. There exists behind the innocuous notion of globalisation, a common difficulty that we have to address. This knot ties together a certain definition of nature and questions what it means to inhabit a territory, the shape of our common abode, and what it means to be a calculating subject. The Empire of the Globe is the name of such a knot. What I wish to do in the second part of this article is to indulge in a bout of speculation about the philosophical origin of the notion of sovereignty, which I take to be in a much wider use than in the field of International Relations proper.

\section{Impenetrability: One Philosophical Origin of the Notion of Sovereignty}

Although sovereignty is a concept apparently restricted to law, political philosophy, and geopolitics, everything happens as if an implicit principle of sovereignty comes into the picture whenever any entity - human or non-human - is defined as distinct from any other and as occupying a certain chunk of space. The reason I choose to go this way is because everything that is tied by such a knot depends on the idea that entities are impenetrable to one another, and are, for that reason, delineated by precise boundaries that define their identity.

It could be the border of a State, what is called, somewhat deceptively, a Westphalian State, ${ }^{23}$ but it could just as well be a society, a biological organism, or any subdivision thereof; a selfish gene for instance, or an organ. The precise nature of those entities does not matter as much as the implicit principle used to localise them. The key concept common to all those examples is that of impenetrability. And of course, such delineation is implied whenever we talk of individual subjects that are supposed to engage in some sort

22. Michel Callon, ed., The Laws of the Markets (Oxford: Blackwell, 1998).

23. Stuart Elden, The Birth of Territory (Chicago: The University of Chicago Press, 2014). 
of commercial or productive relation. Whether you speak of a cell, a sheep, a worker, a nation, or an atom, the boundary that delineates its existence before it enters into relationships is its fortress. It is of every entity and not only of one's homestead that one could claim, as good Englishmen used to say: 'My house is my castle'.

The strange consequence of this apparently commonsense idea that entities are impenetrable to one another, is that they are taken as parts that can then, but only then, enter into relations. Those relations may be planned, as when we assemble the pieces of some implement by following the user's manual that has been offered by the producer, or they may be unplanned. In this latter case, we say that they are 'emergent'. In both cases, we consider the whole as more than the sum of its parts. But there is no question in this view of things that there first exist parts, and then interactions among those parts. However, such a way to order categories is highly debatable. ${ }^{24}$

We should first remark that the very notion of parts entering into relations to form a whole makes sense only if you think of some mechanism and of an assembly line of some sort. ${ }^{25}$ Whatever your vision is of (for instance, a body), it becomes a machine as soon as you claim that you can distinguish the moments when you consider: firstly, parts; secondly, interactions; and finally, wholes. The problem with such a view is that there are parts, literally speaking, only when there is a machine and when there is a constructor, a planner, or some antecedent overbearing figure; some instance that plays the role of assembling the parts in advance. So, whenever we take for granted the idea that there are parts sitting side by side, partes extra partes as a philosopher would say, that means that we are probably thinking of a machine and of a machinist. This is what allows us to consider with disdain any idea that entities could be penetrable. And in the case of machines, this is true; all parts are impenetrable to one another, or at least it is fairly reasonable to think as if this was the case. (I leave aside the worrying fact that when they are considered as projects instead of objects, techniques never actually come to the world in a mechanistic way, a topic I have worked on extensively in the past, but further consideration of which here would lead me astray). ${ }^{26}$

But no matter how ubiquitous machines and machinists are in the contemporary world, they are not everywhere and not everything. I am sure you would agree that most situations do not fit the description of parts and wholes. In most situations where we have some direct experience of following a course of action, the three features that it seems reasonable to identify - parts, relations, and wholes - are not so easily distinguishable: they seem to swirl into one another and to be connected through many folds, as if each one was embedding the others. ${ }^{27}$ This is especially striking, of course, in the case of an

24. Gabriel Tarde, Monadology and Sociology, trans. Theo Lorenc (Melbourne: re.press, 2012 [1895]); Bruno Latour, Pablo Jensen, Tommaso Venturini, et al., “"The Whole is Always Smaller Than its Parts" a Digital Test of Gabriel Tarde's Monads', British Journal of Sociology 63, no. 4 (2012): 591-615.

25. Raymond Ruyer, Néo-finalisme (préface de Fabrice Colonna) (Paris: PUF, 2013 [1952]).

26. Bruno Latour, Aramis or the Love of Technology (Cambridge: Harvard University Press, 1996).

27. Gilles Deleuze, The Fold: Leibniz and the Baroque, trans. Tom Conley (London: Athlone Press, 1993). 
organism. Every 'part' (now in quotation marks) is simultaneously the whole and part/ whole relations. ${ }^{28}$

This does not mean that it is 'organic' in the usual meaning of the word, as if there was an overall order superior to the parts, but that the three usual notions of parts, wholes, and relations, have to be constantly redistributed. Even if an organism is not especially organic, it is at least certainly not a machine made of parts that can be assembled. ${ }^{29} \mathrm{Or}$, to put it in another way, 'organicism' does not qualify a living organism better than 'mechanism'. Which does not mean that there are not many phenomena that could be described as machine-like and others as organicist-like, but rather that those terms don't qualify well the situation of the envelopment of the parts, of the wholes, and of the relations. In other words, nowhere could an ersatz of the principle of sovereignty describe what is in question in living organisms.

So, if nowhere in experience do we encounter the tripartition of parts, interactions, and wholes, except practically for reasons of control, why is it taken as a commonsense cosmology to the point that if there is one thing of which we are all convinced, it is that the impenetrability of entities is a given? Not many people have attempted to explain this curious deviation from experience. And none has gone further and more radically so than Alfred North Whitehead. Although his argument is speculative, it is in no way abstract or far-fetched. Building on Bergson, he simply asks, especially in The Concept of Nature, ${ }^{30}$ that we focus on what we mean when we localise a feature of the world. The focus is important because it is here that we see the odd notion of the Globe we have inherited and then expanded everywhere.

When we localise a point, an atomic point, Whitehead argues, then by definition we need a system of coordinates that allows such an atom of matter, or a moment of time, to be defined. The operation seems to be innocuous enough: it seems as easy as clicking on a Google map to pinpoint a destination. And yet, what is left totally out of the picture is the instrument that formats any encounter with any part of space-time, with respect to such a frame of reference and to no other. Actually, I am wrong in what I just said: it is because the coordinates are in place that we believe we are allowed to talk of a portion of space-time as being nothing more than a chunk of space-time. There are parts because there is a localisation process. Once this operation has been done, there is no turning back: the entity will be grasped as necessarily having a border that defines its identity, and the smaller the entity, ideally a material point and an instant of time, the stronger will be the impression of having 'fully defined it', which means now to have localised it.

28. Bruno Latour, 'Gabriel Tarde. La société comme possession. La preuve par l'orchestre', in Philosophie des possessions, ed. Didier Debaise (Dijon: Les presses du Réel, 2011), 9-34; Scott F. Gilbert and David Epel, Ecological Developmental Biology: The Environmental Regulation of Development, Health and Evolution (Sunderland: Sinauer Associates, Inc, 2015).

29. Deborah Gordon, 'The Ecology of Collective Behavior', PLoS Biol 12, no. 3 (2014): 1-4.

30. Alfred North Whitehead, The Concept of Nature (Cambridge: Cambridge University Press, 1920); Isabelle Stengers, Thinking with Whitehead: A Free and Wild Creation of Concepts, trans. Michael Chase (Cambridge: Harvard University Press, 2011). 
Whitehead's argument is speculative, but there would be many ways to make it empirical by looking at the history of cartography, of surveying, of collections, and countless other formatting devices. ${ }^{31}$ To be a material entity is first to be localised in this way. But where is the system of coordinates itself? Who manages the cosmic order that is capable of such a feat? This is never underlined. We accept to begin from localisation in time and space - this land, this site, this moment, this city, this individual agent, etc. - but we never trace our way back to the formidable instrument that enables the attribution of coordinates (no more than we have any idea of the vast network of computers that allows digital maps to come to our mobile phones).

This is why I used the term 'Empire of the Globe'. It defines an invisible power inside which everything else could be located even though the frame allowing the localisation remains totally invisible. The power to localise while remaining invisible, you would agree, is the imperial power par excellence. And this is not a metaphor, since inevitably, once there are parts there is also lurking somewhere in the background an Engineer, a Dispatcher, a God figure of some sort, whose all-seeing Eye is able to offer localisation to any chunk of space-time. The mechanistic view of matters, as Whitehead shows so forcefully, is the consequence of the principle of localisation and of the invisible system of coordinates that allows such a localisation to occur.

Of course, he had no intention of linking such a speculative argument either to geopolitics (the bounded nature of Westphalian States, each exerting sovereignty over its own territory) or still less to ecological questions (even though he was well aware they would take prominence soon enough). Still, it is not for nothing that he called his philosophy a 'philosophy of organism'. It was crucial for him to generate a philosophy of nature freed from the main feature that the 17th century had inserted into it: namely, the distinction between primary and secondary qualities generating what he called 'the bifurcation of nature' into two incompatible systems, 'conjecture' and 'dream', to recall his famous sentence:

What I am essentially protesting against is the bifurcation of nature into two systems of reality, which, in so far as they are real, are real in different senses. One reality would be the entities such as electrons which are the study of speculative physics. This would be the reality which is there for knowledge; although on this theory it is never known. For what is known is the other sort of reality, which is the byplay of the mind. Thus there would be two natures, one is the conjecture and the other is the dream. ${ }^{32}$

He was convinced, and so am I, that such a 'nature' is uninhabitable for any form of existence. Still, this is the one that has been expanded to the whole world as the only way to localise any entity before its relations are to be deployed. But Whitehead was also convinced that the alternative was not some sort of an 'organicist' view of nature, since such a view would have had no other result than to bind together elements that would

31. Christian Jacob, The Sovereign Map: Theoretical Approaches in Cartography Throughout History, trans. Tom Conley (Chicago: The University of Chicago Press, 2006).

32. Whitehead, The Concept of Nature, 30. 
remain separated anyway by the principle of localisation, as if there were parts, and in addition, some sort of whole. Whitehead's philosophy of organism is the polar opposite of any organicist or holistic view of nature. ${ }^{33}$ To overcome an artifact, one cannot simply sweep it under the rug; rather, one has to go back to the situation that created it in the first place and restart with another solution in hand. Any 'organicist' view of nature is an attempt to hide the problem of localisation without even attempting to remedy it. And remedy it we must. The Globe is not there to be populated but to be recalled and reset. ${ }^{34}$

\section{Sovereignty Suffers from the Weakness of the Principle of Localisation}

Such a reset is especially important for debugging four successive artifacts that are going to be triggered as so many consequences of the principle of localisation, each of them contributing to the invention of a notion of a physical Globe that will become the 'basemap' for situating any entity and any conflict. As a result of such a principle, nationstates, pinpointed on maps, are going to have to live through a definition of their existence that bears no relation whatsoever with their experience! In addition to their internal relations, scholars as well as heads of State will be forced to add 'international' relations, as if those were a sort of afterthought. Such a strange state of affairs is the result of four unwanted outcomes of localisation: relation, scale, causality, and agency.

\section{The Notion of Relation}

The first artifact created by the principle of localisation is the apparently innocuous notion of relation. In spite of what appears to be the case, there is nothing obvious in asserting that entities 'enter', 'depend on', or 'are best understood through', their relations with others. Naturally, it is better and more accurate than to say that entities should be studied in isolation. But, adding relations to an entity in no way overcomes the difficulty of having already traced a firm boundary around it. The principle of localisation pre-forms the entity - a chunk of time and space - as if it existed just like that, all by itself, even if there is no time before it and no space around it. When you then add relations into which this atomic entity is said to 'enter', you begin to fall into all the conundrums on which social theory, biology, political sciences, economics, and geopolitics, are grinding their teeth: what traits should be allocated to the relations, and which ones to the 'inner' properties of the entity? The answer is that the question has been rendered meaningless, since the principle of localisation has created an artifact; a phantom that no amount of relations can resuscitate afterwards.

When anyone begins to speak of the relations inside which any entity is supposed to 'enter', it is too late. In economics, you cannot study the individual calculator and then

33. Bruno Latour, 'How to Make Sure Gaia Is Not a God of Totality', Theory, Culture \& Society (Forthcoming, 2016).

34. Bruno Latour and Christophe Leclercq, eds., Reset Modernity! Catalogue of the Exhibition (Cambridge: MIT Press, 2016). 
add the market to understand its behaviour, any more than you can define the selfish gene of a cell and then the organism into which it enters, or, for that matter, to start with the interest of a nation-state and then try to see how it is 'influenced' by its global environment. The qualities that the relations bring to the entity were there all along, except that they had been cut off by the principle of localisation. But those qualities were playing their role earlier in a totally different manner, a manner that has now disappeared and is totally irretrievable. What has been severed cannot be tied together again, because the traits brought in later are not the same: a complete metamorphosis has occurred, rendering the belated addition of relations to an entity meaningless.

To put it more starkly, an entity plus its relations, or an organism plus its environment, remains a monster no matter what you do afterwards to retie it. This is, of course, for those who are cognisant of my work, the basis of the actor-network theory, or of Tarde's monadology. ${ }^{35}$ It is not, as some philosophers argue, that relations precede entities (as if we had to choose between two opposite artifacts $)^{36}$ but that the very notion of relations among entities is misguided - or simply too belated to be of real speculative significance except for practical purposes. In that sense, international relations always precede internal relations.

\section{The Notion of Scale}

Another artifact created by the principle of localisation is the strange idea of scale. Nothing has thwarted the development of geopolitics more than the idea that there exists some sort of scale along which one could go from the 'local' to the 'global'. This idea is the bane of ecology, but also of geopolitics, and of course, as I have shown many times, of social theory with its cumbersome invention of 'society' ${ }^{37}$ Even though it seems commonsensical enough to say that we should define the scale at which we describe a phenomenon, it takes only a moment's attention to the procedure of thought (which most often is a procedure of visualisation and of cartographic projection) to realise that it is entirely an artifact of the principle of localisation.

Here, we should not be taken in by the habit of clicking on digital maps to 'zoom in and out' of a locality, as we say, thanks to the plus $(+)$ or minus $(-)$ icon. What we call the 'larger scale' is not what surrounds a local site to serve as its environment; it is exactly the same features present at the smaller scale, simply differently distributed. If on a geopolitical map you first click on Aleppo before 'enlarging' the scope of the image to include 'all of Syria', what you get are elements that were already parts of Aleppo - roads going to it, a mountain range long present there, ethnic groups that define the plausible reaction to the extension of this or that battle front, business interests that have always cast a long shadow on Aleppo's wealth, etc. It is very true that the minus icon gives you more because it is

35. Bruno Latour, Reassembling the Social: An Introduction to Actor-Network Theory (Oxford: Oxford University Press, 2005); Tarde, Monadology and Sociology.

36. Graham Harman, Prince of Networks: Bruno Latour and Metaphysics (Melbourne: re.press, 2009).

37. Bruno Latour, Reassembling the Social. 
more readable, but it is not the discovery of things 'bigger', 'larger' or 'more encompassing'. It is the unfolding or deployment or stressing or underlining of features that were present in the former case, but were not as easily visible. 'Small' is never inside the big, small is merely a way to underline some aspects of the big. As to what we mean by 'big', it is merely a way to emphasise some aspects of the overlapping smalls. ${ }^{38}$

Once again, it is because the localisation (in this example, the plus icon) has first cut off all the links, that you are surprised to find more when you click on the minus icon. No wonder: if you have first pushed everything aside to pinpoint a local spot, it is not so surprising that you need to add a lot of stuff afterwards to make sense of the isolated point. But the question should be: why did you start by drawing a dimensionless point? In the close-up view, the large scale, you had first externalised everything else! When you zoom out to the small scale, you get the 'big picture' of the relations in which the local site 'is to be situated'. If the big picture is always, I dare say, a big picture, that is a mistake - or rather a habit - due to the way we organise cartography, and then use maps mentally as the all-purpose tools for any localisation whatsoever. There must be other ways to display features than first localising (and thus cutting off all links) and then adding relations dramatised and regrouped as the 'context' in which the first entity has been situated. Long before Google Maps showed the artificiality of such a zoom, actor-network theorists were well aware of the fallacy.

\section{The Notion of Causality}

But the third artifact created by the principle of localisation is the most damning one. By cutting off a chunk of time and space as if the excised or cutout entity had no antecedent in time and no neighbour in space, as Whitehead would say, you create the great puzzle of understanding how this entity is going to influence or experience the effect of any of the other chunks of space and time similarly cut out. This is the conundrum artificially created by the principle of localisation to which Bergson, James, and Whitehead objected, but which seems to have been maintained, in spite of their critique, no matter the absurdity of the procedure it implies.

The makeshift solution is to say that the world is made of inanimate atoms of matter that are then connected by cause and effect relations. What is so bizarre in this solution is that the isolated chunks of space and time are in fact related, but not by any realistic set of connections. As I just said with scale, 'causality' is not a way to capture the features of any situation, but is a distribution of traits after all connections have been cut off. The only way to understand that a billiard ball hits another billiard ball once you have isolated the ball from everything else (the table, the game, the participants, the green felt cover, the rules, etc.), is to be left with nothing else but the 'toc' of one similarly atomised ball, hitting on, and pushing it, slightly. The principle of cause and effect, just like scale

38. Gabriel Tarde, Social Laws: An Outline of Sociology, trans. Howard C. Warren (Kitchener: Batoche Books, 2000 [1899]); Bruno Latour, 'Tarde's Idea of Quantification', in The Social after Gabriel Tarde: Debates and Assessment, ed. Mattei Candea (London: Routledge, 2010): $145-62$. 
or relation, is in no way a commonsense universal organisation of the ways things are. Causality is a highly peculiar staging of the procedures of thought to render understandable a tiny number of traits, and render totally incomprehensible a vastly greater number. Such a Faustian bargain, by the way, is a good definition of naturalism.

Of course this price is worth paying in many situations. Great progress is made by those who localise parts, add relations, build mechanisms, link elements with cause and effect relations, and build a scale model of the whole set up. The advantage of such a procedure is not in question. ${ }^{39}$ What is in question is why such a wholly practical procedure invented for the necessities of engineering has been turned into metaphysics. This is when materiality is lost and an idealistic definition of matter takes over and replaces ontology by the procedure of thought. At this point, the world is made of the way we know it; ${ }^{40}$ a curious lack of realism is introduced into a purposely realistic and fact-based 'scientific world view' that has become totally unscientific. There is no problem with physics per se; the problem starts when it is transformed into a view of the world. It is hard to understand why geopolitics should inherit anything from a metaphysics that is unable to render justice to the practice of physics anyway.

\section{The Notion of Inanimate Entities}

After an entity has been localised, the strangest feature of the cause and effect staging is that there is a great price to pay for the de-animation that is associated, in the minds of most people, with such a 'scientific world view'. Things have lost all agency. Or rather, agency has been granted to the external causes that have the magical ability to traverse them entirely. While the detached, atomised chunks of space-time - disposed separately as so many pearls on a thread - are totally de-animated, the principle of causality appears, nonetheless, to penetrate all of them fully. If not, they would not be able to act at all.

It is not always recognised how paradoxical it is, not to say perverse, that cause is supposed to influence consequences. You remember that the principle of localisation is what allows common sense, apparently, to consider the impenetrability of entities as a given. By this is meant impenetrability by one another (which is, as we now understand, not a given at all but the consequence of localisation). And yet the effect (the chunk of space-time next in line) is totally permeable to its cause. The pearls are indeed connected by a thread, and what a thread! Causality has the miraculous aspect of totally impregnating the effect and still letting the effect have its own standing (if not, it would be sufficient to simply state the cause to have the effect in potentia).

This is the great perversity of the cause and effect relation: a) it simultaneously withdraws agency from the effect to put it all in the cause; b) it lets the cause totally penetrate the effect; and yet c) it lets the effect have some residual agency, that of carrying the causality one step further (what I call in my jargon acting as an intermediary and not a

39. I thank Gerard de Vries for underlining this point and directing me to Stephen Toulmin, The Philosophy of Science: An Introduction (New York: Harper \& Row, 1960).

40. Bruno Latour, An Inquiry into Modes of Existence. An Anthropology of the Moderns, trans. Catherine Porter (Cambridge: Harvard University Press, 2013). 
mediator). Is it not extraordinary that it is that arrangement that passes for obvious and that it is the penetrability of entities that sounds odd? Is it not extraordinary that to avoid the consequences of the penetrability of entities, a procedure has been imagined by which all entities are cut off from one another and then bounded again, if I may say, in such a way that there exists one single bundle, that is, a material world simply obeying the universal laws of nature?

If you consider such a conception of physics for even five minutes, you cannot avoid concluding that a totally exotic form of metaphysics has been created. Under the principle of the separability of entities considered partes extra partes, has been created, in effect, a complete penetrability of all entities, but with this difference: what connects all entities together are 'universal laws of nature' that have no localisation, and that penetrate, without contact, a multiplicity of chunks of space and time devoid of any agency.

It is often said that political theory has been built on scientific materialism. My impression is that the genealogy goes in reverse. Physicists appear to have borrowed from Hobbesian models of the state how to imagine a local entity with its own sovereignty, which then enters into relations with bigger entities and is submitted to the effect of causality reigning over material entities with no agency whatsoever. If the concepts of relations, scale, causality, and de-animation could be of some use for the practical tasks of engineers and scientists, it would be a miracle if they helped social scientists provide a plausible description of geopolitics.

\section{Behind the Globe, the Emergence of the Earth}

Well, it is this exotic vision of nature that Europe, and then more generally the West, has sold to the rest of the world as the real, earthly, natural, material world... And all the other collectives, those who had many other ways of assembling entities, were rendered archaic, exotic, premodern, and irrational by comparison! Am I really wrong in thinking that this is the Globe that it is the responsibility of Europe to recall? Again, 'recalling' in the sense that we recall a memory, and trace it back through history and the philosophy of science to see how it is that such a perverse and improbable procedure has been generated and expanded everywhere - how the res extensa has been literally extended - but 'recalling' also in the business sense, of bringing back a badly designed product so it is debugged and refitted.

All people of the world have bought from us, the Europeans, a product that was supposed to give them access to the secular material world. And it is true they were sold a product that allowed a few features to be easier to calculate and detect, but at the enormous price of breaking with all reasonable experience. Once again, as a procedure, the principle of localisation is magnificent and probably indispensable in many situations and for many walks of life. However, it is when it has been transformed into metaphysics and then into ontology that it has become not only incoherent, but also poisonous. Naturally, good scientists are quick to jettison the so-called 'scientific world view' every time they realise it is going to make them miss important discoveries, but this is not so for the poor folks who really believe that such a procedure of localisation describes the world as it is. 
I think I have said enough to show you why the theme of the Globe and Europe cannot be treated as if the Globe was an unproblematic concept. The link is much older, much more complex, and infinitely much more political. The Globe as an inhabitable dreamland of metaphysics has been proposed as the universal and global habitat of everything that lives and exists. It is no great surprise that we all have a responsibility in recalling, or if you prefer, in reclaiming such a production. I also hope that I have convinced you that Peter Sloterdijk was right in identifying Europeans by their memory, their precise recollection, of the Empire. Not in the sense that they wish once again to be the centre of the world - they have done enough in that respect! - but in the much more interesting sense of exploring an alternative to the notion of Empire and of sovereignty.

To hold in one's hand the onus orbis terrarum, that is, the weight of the terrestrial globe, used to be a mythical figure of speech associated in the old days with the decorum of imperial, and later, Christian, paraphernalia. With the ecological mutation, it has taken a very practical meaning: after all, what were the nation-states assembled in Paris in December 2015 doing at the United Nations Framework Convention on Climate Change conference (COP21) if not trying to negotiate a way to share the weight of the Globe that they had collectively brought to bear on their shoulders? ${ }^{41}$ If there was one thing clear in such an assembly, it was the complete unrealism of their borrowed notion of sovereignty: sovereign states framed by sharp borders were discussing how to collectively bear something that crossed through all borders, and that over a few centuries had entangled them much more tightly than war or commerce had ever been able to do. The return of natural entities such as $\mathrm{CO}_{2}$ into politics thus offers an excellent occasion to purge the notion of sovereignty of the odd physics that had been inserted into it in earlier days. With COP21 it has become even clearer that geopolitics does not have the same meaning at all, whether the suffix 'geo' means the older Globe of the first imperial history, or the newly emerging Earth. The etymology is the same, not the destiny.

\section{Acknowledgements}

Thanks to the Millennium journal editorial board for their invitation, and especially to Scott Hamilton for his help in navigating the field of International Relations for a total outsider.

\section{Funding}

This research received no specific grant from any funding agency in the public, commercial, or not-for-profit sectors.

\section{Author Biography}

Bruno Latour is Professor at Sciences Po (Paris) and Director of its Médialab.

41. The 2015 Paris Climate Conference, also known as COP21, was the 21 st Conference of the Parties (COP) conducted under the auspices of the UN's Framework Convention on Climate Change (UNFCCC), 30 November-12 December, 2015, in Paris, France. 